\title{
Physiological zinc-binding proteins of medium molecular weight in the rat gut
}

\author{
BY MALCOLM J. JACKSON \\ Department of Medicine, University of Liverpool, PO Box 147, Liverpool L69 $3 B X$ \\ AND DAPHNE HOLT AND MICHAEL WEBB \\ Toxicology Unit, MRC Laboratories, Woodmansterne Road, Carshalton, \\ Surrey SM5 $4 E F$ \\ AND NICHOLAS D. CARTER \\ Department of Child Health, St. George's Hospital Medical School, Cranmer Terrace, \\ London $S W 17$
}

(Received 20 May 1985 - Accepted 8 October 1985)

1. Gel filtration on Sephadex G 75 was used to separate the medium-molecular-weight zinc-binding proteins from the soluble fractions from the duodenal and jejuno-ileal segments of the rat gut at 30 min after the intragastric administration of a tracer dose of ${ }^{65} \mathrm{Zn}$. These proteins were resolved by ion-exchange chromatography on DEAE cellulose.

2. In both the duodenum and jejuno-ileal segment an appreciable fraction of the total soluble $\mathrm{Zn}$ was bound in a protein fraction that resembled metallothionein (MT) in its behaviour on gel filtration. These fractions, however, were not homogeneous, but contained several medium-molecular-weight $\mathrm{Zn}$-binding proteins. In the duodenum, but not in the jejuno-ileal segment, two of these proteins appeared to be the isometallothioneins, ZnMT-I and ZnMT-II.

3. These results suggest a possible role for MT in the binding of newly-absorbed $\mathrm{Zn}$ in the duodenal mucosal cells. They also show that gel filtration alone is insufficient for the identification of MT in the intestine.

The recognition of human pathological disorders, such as acrodermatitis enteropathica (Moynahan, 1974) and coeliac disease (Elmes et al. 1976), in which defects in zinc absorption may play an important role, has led to many attempts to elucidate the absorptive mechanisms and pathways in animals and man (Hurley et al. 1977; Cousins, 1979; Davies, 1980; Starcher et al. 1980; Jackson et al. 1981; Bonewitz et al. 1982; Sugawara, 1982). One major area of contention has been the possible role of the medium-molecular-weight (MMW) protein, metallothionein (MT), in the process of absorption. The two isomers of this metalloprotein have been isolated from the small intestine of the adult rat after either parenteral injection of $\mathrm{Zn}$ or oral administration of cadmium, and characterized unequivocally by their amino acid compositions (Richards \& Cousins, 1977; Taguchi \& Nakamura, 1982). The observation of an inverse relation between the intestinal MT concentration and the transfer of $\mathrm{Zn}$ to the portal circulation led Richards \& Cousins (1975, 1976; see also Cousins, 1979) to suggest that this metalloprotein regulates the transport of newly-absorbed $\mathrm{Zn}$ through the mucosal cells to the carrier-proteins in the plasma. This hypothesis was rejected by Starcher et al. (1980) who concluded that the rate of $\mathrm{Zn}$ absorption is related directly to the intestinal concentration of MT, which functions as a transport protein. This conclusion, however, now seems untenable since, according to Flanagan et al. (1983), $\mathrm{Zn}$ absorption in the mouse is unaffected by the concentration of MT in the intestine.

As much of the above-mentioned work was done with non-physiological doses of $\mathrm{Zn}$, it is possible that the accumulation of mucosal $\mathrm{ZnMT}$ is not (part of) a homeostatic mechanism, but is due either to saturation or to the breakdown of normal regulatory control 
(Bremner, 1982). Whilst it is clear that either parenteral or oral administration of a single dose of $\mathrm{Zn}$ leads to the temporary accumulation of $\mathrm{ZnMT}$ in the intestine (see e.g. Richards \& Cousins, 1975; Menard et al. 1981), and there is a direct correlation between elevated dietary Zn intake and mucosal MT content (Hall et al. 1979; Olafson, 1983), it remains to be established whether the low concentration of the metalloprotein in the intestine of unsupplemented rats (Hall et al, 1979) is relevant to the absorption of $\mathrm{Zn}$ under normal physiological conditions. To investigate this, a study has been made of the binding of ${ }^{65} \mathrm{Zn}$ to the MMW proteins of the mucosal layers of the duodenum and jejuno-ileal segment of the rat gut at $30 \mathrm{~min}$ after an oral dose. Since the transfer of $\mathrm{Zn}$ from the lumen to the wall of the small intestine occurs very rapidly (Jackson et al. 1981), whereas the induced synthesis of MT is not immediate (see e.g. Menard et al. 1981), it was considered that only the endogenous $\mathrm{Zn}$-binding proteins would be labelled in significant amounts at this time.

\section{MATERIALS AND METHODS}

\section{Animals and treatments}

Male Wistar rats were used for all experiments. They were maintained on a standard laboratory diet and were fasted for $24 \mathrm{~h}$ before and throughout the experiments to ensure that the stomach and small intestine were relatively free of digesta. For studies on the physiological $\mathrm{Zn}$-binding MMW proteins, each animal received $4 \mu \mathrm{Ci}{ }^{65} \mathrm{Zn}$ (Amersham International plc, Amersham, Bucks) supplemented with zinc chloride $(0.25 \mu \mathrm{mol})$. At $30 \mathrm{~min}$ after the administration of the dose in $0.5 \mathrm{ml}$ distilled water via a stomach-tube, each rat was killed by exsanguination under diethyl ether anaesthesia. The entire gut was removed immediately, cleaned of extraneous tissue and dissected to separate the duodenal and jejuno-ileal segments. These were washed with $1-2 \mathrm{ml}$ cold isotonic saline $(9 \mathrm{~g}$ sodium chloride/1) to remove the gut contents and then cut lengthwise with scissors. The mucosal cells were removed with a glass slide and either processed immediately or frozen in liquid nitrogen $\left(-197^{\circ}\right)$ until required. ZnMT was induced in the liver and intestine by the intraperitoneal injection of $\mathrm{ZnCl}_{2}(25 \mu \mathrm{mol})$, the animals being killed by decapitation after $18 \mathrm{~h}$ (Richards \& Cousins, 1975). The livers and mucosal cells, separated from the isolated mucosal segments as described previously, were stored frozen in liquid $\mathrm{N}_{2}$.

\section{Analytical methods}

The mucosal cells from the appropriate intestinal segments from at least four rats were pooled, suspended in ice-cold $10 \mathrm{~mm}$-ammonium formate buffer, $\mathrm{pH} 8.0(5 \mathrm{ml}$ or 3 vol. for tissue weights $<1 \mathrm{~g}$ and $>1 \mathrm{~g}$ respectively), and homogenized in a motor-driven PotterElvejhem homogenizer. The soluble fractions were separated by centrifugation $(140000 \mathrm{~g}$ for $45 \mathrm{~min}$ at $5^{\circ}$ ) and applied to columns of Sephadex G 75 (Pharmacia Ltd, Milton Keynes). The columns were eluted at $5^{\circ}$ with $10 \mathrm{~mm}$-ammonium formate buffer, $\mathrm{pH} 8 \cdot 0$, at a flow-rate of either $8-10 \mathrm{ml} / \mathrm{h}$ or $13-14 \mathrm{ml} / \mathrm{h}$ (see p. 372), fractions (either $3 \mathrm{ml}$ or $4 \mathrm{ml}$ in volume) being collected automatically. After analysis (see p. 374), the MMW fractions for each column were combined and lyophilized. The residual solid was dissolved in the same buffer $(10 \mathrm{ml})$ and fractionated (fraction vol. $3 \mathrm{ml})$ on a column $(300 \mathrm{~mm} \times 15 \mathrm{~mm})$ of Whatman DEAE cellulose (Uniscience Ltd., Cambridge) with a linear gradient of 10-200 mmammonium formate buffer, $\mathrm{pH} 8 \cdot 0$, at a flow-rate of $28-30 \mathrm{ml} / \mathrm{h}$ as eluant. In one experiment, in which protein-bound $\mathrm{Zn}$ was replaced by $\mathrm{Cd}$ under anaerobic conditions, $\mathrm{N}_{2}$-purged buffers were used for the preparation and fractionation of a duodenal homogenate. The MMW fraction from the gel-filtration column was transferred directly to a DEAE cellulose column, pre-equilibrated with $\mathrm{N}_{2}$-saturated $10 \mathrm{mM}$-ammonium formate buffer. 


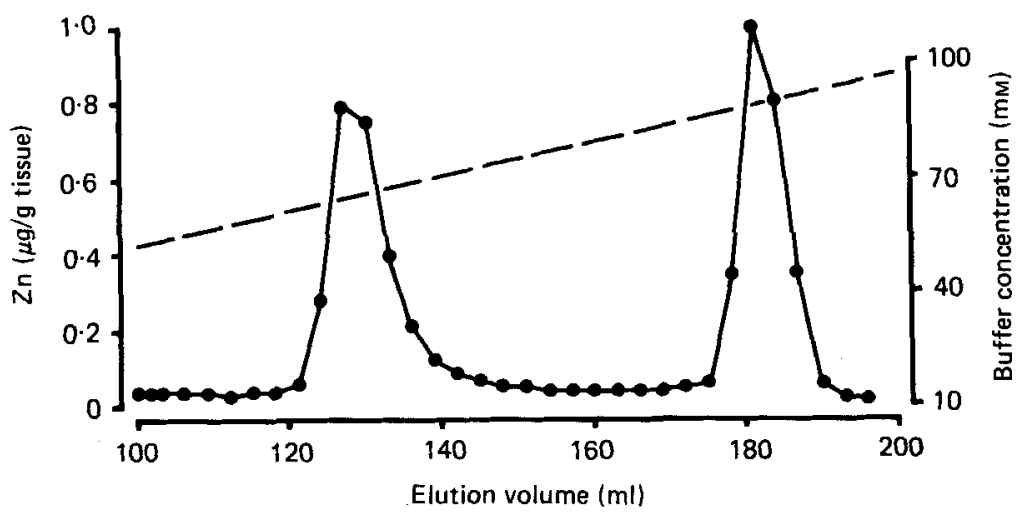

Fig. 1. Separation of the isomeric forms of zinc metallothionein (MT) induced in the intestine of the male rat by the intraperitoneal injection of zinc chloride $(25 \mu \mathrm{mol})$. The $\mathrm{ZnMT}$, isolated from the soluble fraction of the mucosal cells by gel filtration on a column $(900 \mathrm{~mm} \times 15 \mathrm{~mm})$ of Sephadex G 75 , was fractionated by ion-exchange chromatography on a column $(300 \mathrm{~mm} \times 15 \mathrm{~mm})$ of DEAE-cellulose with a linear gradient (--) of $10-200 \mathrm{mM}$-ammonium formate buffer, $\mathrm{pH} 8.0$, as eluant. The MT isomers, ZnMT-I and ZnMT-II, were eluted at buffer concentrations of $65 \mathrm{~mm}$ and $88 \mathrm{~mm}$ respectively.

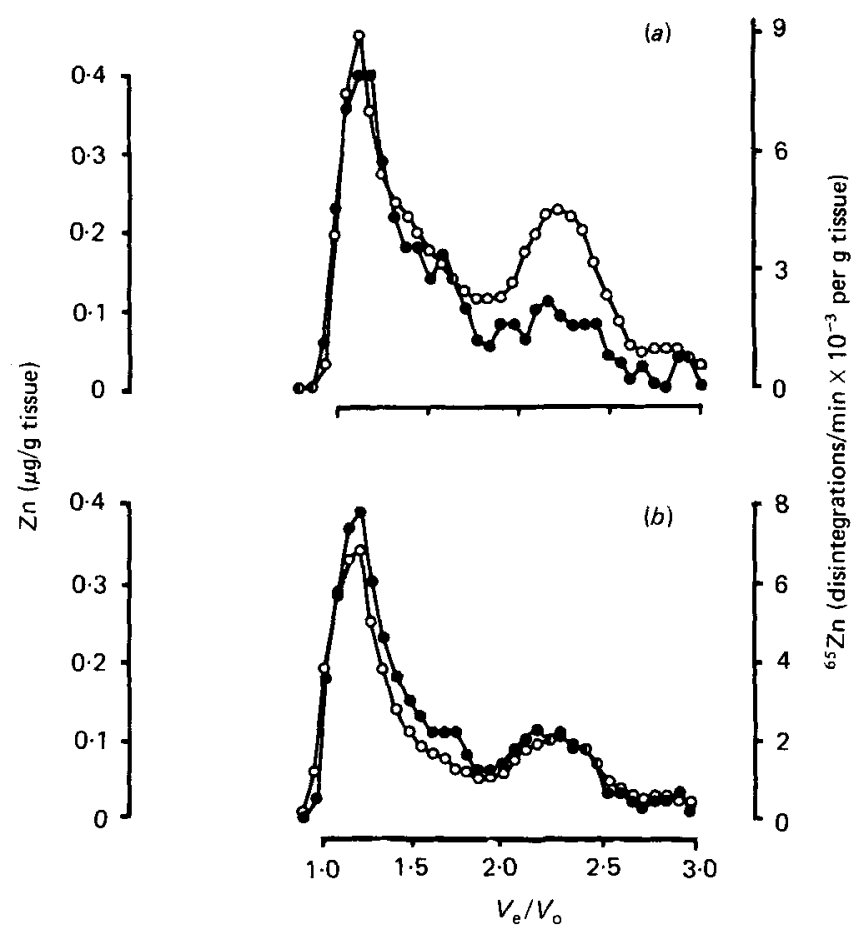

Fig. 2. Elution profiles (elution volume $\left.\left(V_{\mathrm{e}}\right)\right)$ /void volume $\left(V_{\mathrm{o}}\right)$ ) of zinc $(\Theta)$ and ${ }^{65} \mathrm{Zn}(O)$, obtained by gel filtration on columns $(900 \mathrm{~mm} \times 15 \mathrm{~mm}$ ) of Sephadex $G 75$, of the soluble fractions from the mucosa of $(a)$ the duodenum and $(b)$ the jejuno-ileal segment of the intestine of the male rat at $30 \mathrm{~min}$ after the intragastric administration of a tracer dose of ${ }^{65} \mathrm{Zn}(4 \mu \mathrm{Ci} ; 16 \mu \mathrm{Ci} / \mu \mathrm{mol}$ zinc chloride). 


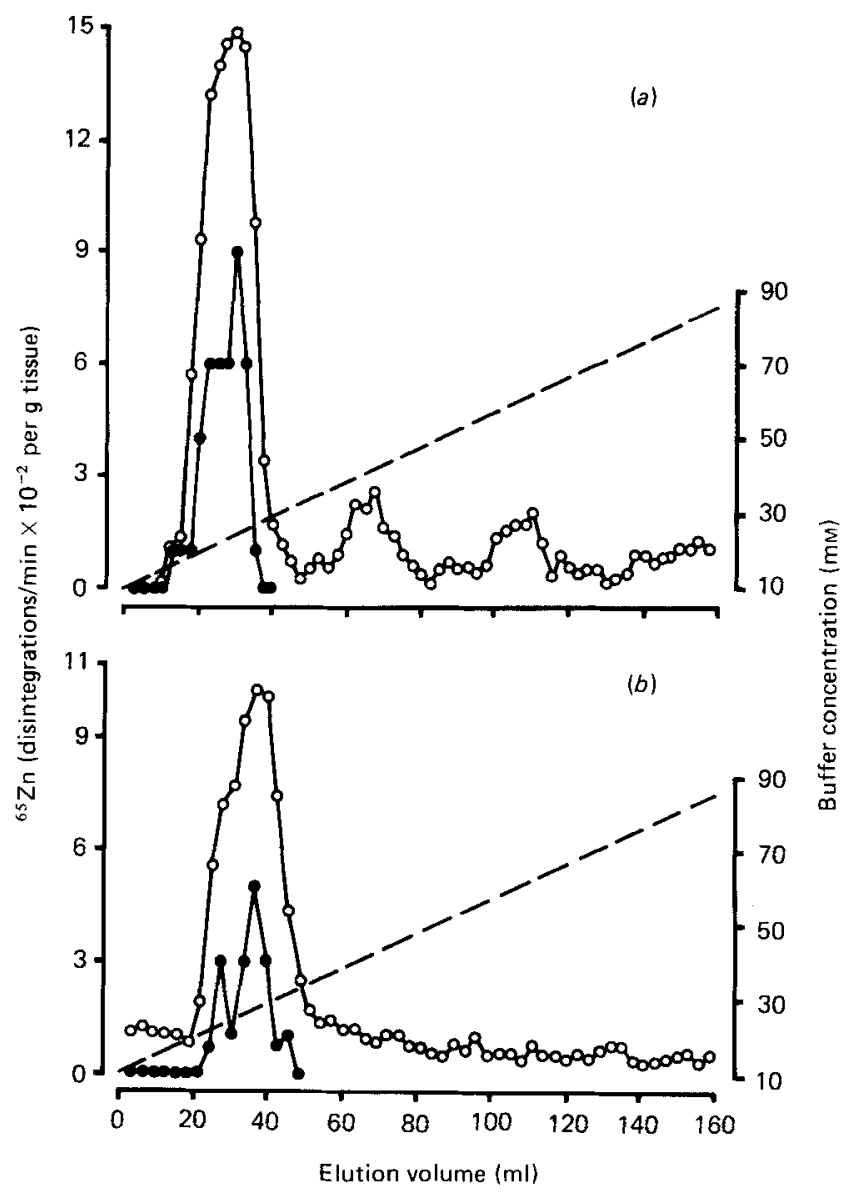

Fig. 3. Ion-exchange chromatography on a DEAE-cellulose column $(300 \mathrm{~mm} \times 15 \mathrm{~mm})$, with a linear gradient (--) of 10-200 mM-ammonium formate buffer, $\mathrm{pH} 8 \cdot 0$, as eluant, of the physiological medium-molecular weight, ${ }^{65} \mathrm{Zn}$-labelled, $\mathrm{Zn}$-binding-protein fractions (see Fig. 2) from (a) the duodenum and $(b)$ the jejuno-ileal segment of the rat intestine. $\mathrm{Zn},(O) ;{ }^{65} \mathrm{Zn},(\mathrm{O})$.

Column fractions were analysed for $\mathrm{Zn}$ and $\mathrm{Cd}$ by atomic absorption spectrophotometry and for ${ }^{65} \mathrm{Zn}$ in an Auto-gamma Scintillation Spectrometer (Model 5330; Packard Instruments Ltd., Caversham, Berks).

\section{RESULTS}

The ZnMT that was induced in the rat intestine by the intraperitoneal injection of $\mathrm{ZnCl}_{2}$ $\left(25 \mu \mathrm{mol}\right.$ ) was isolated as a single peak (elution volume $\left(V_{\mathrm{e}}\right) /$ void volume $\left.\left(V_{\mathrm{o}}\right) 1.9-2 \cdot 0\right)$ from the soluble fraction of the mucosal tissue by gel filtration on a column of Sephadex G 75 $(900 \mathrm{~mm} \times 15 \mathrm{~mm})$ with $10 \mathrm{~mm}$-ammonium formate buffer, $\mathrm{pH} 8.0$, at a flow-rate of $8-10 \mathrm{ml} / \mathrm{h}$ as eluant. The crude metalloprotein was resolved by ion-exchange chromatography or a DEAE-cellulose column as described previously into the isometallothioneins, ZnMT-I and ZnMT-II, which eluted at buffer concentrations of $65 \mathrm{~mm}$ and $88 \mathrm{~mm}$ respectively (Fig. 1).

On gel filtration, under identical conditions, of the soluble fraction of the mucosal cells 


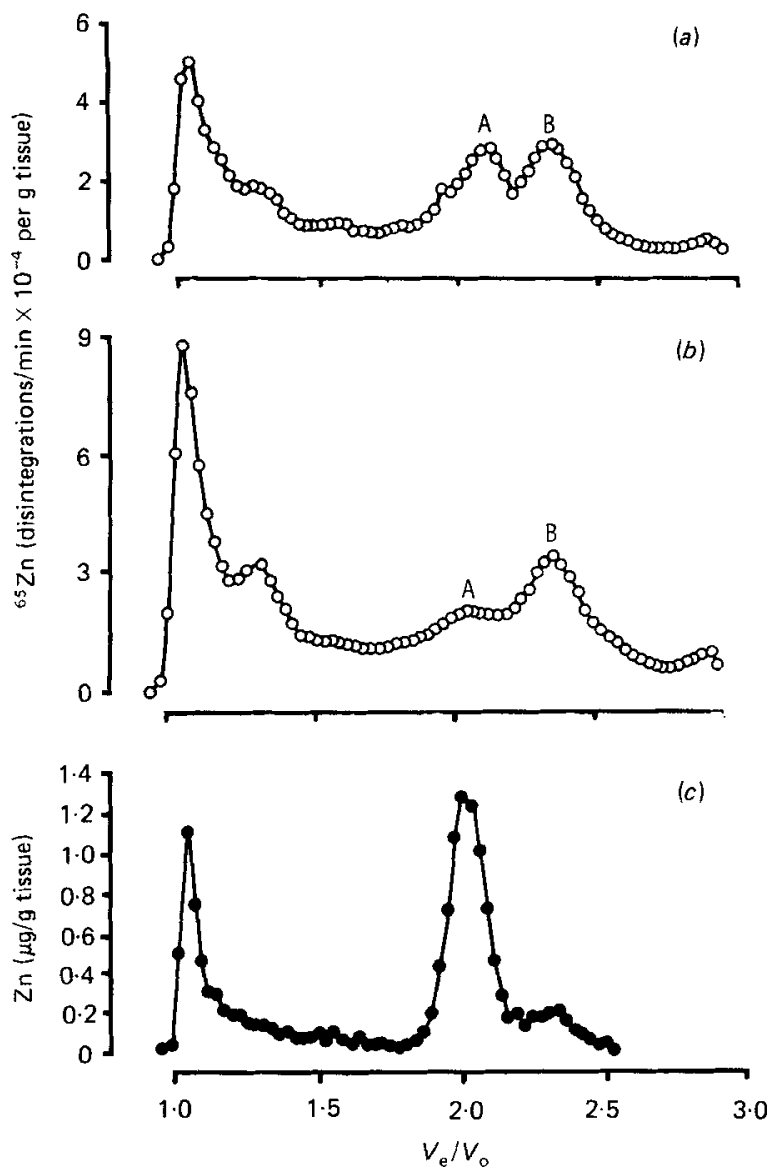

Fig. 4. Elution proffles (elution volume $\left(V_{\mathrm{e}}\right) /$ void volume $\left(V_{0}\right)$ ) of ${ }^{65} \mathrm{Zn}(O)$ or $\mathrm{Zn}(O)$ obtained by gel filtration on columns $(900 \mathrm{~mm} \times 25 \mathrm{~mm}$ ) of Sephadex $\mathrm{G} 75$ with $10 \mathrm{~mm}$-ammonium formate buffer, $\mathrm{pH}$ 8.0 , at a flow-rate of $13-14 \mathrm{ml} / \mathrm{h}$ as eluant, of the soluble fractions from the mucosa of $(a)$ the duodenum and $(b)$ the jejuno-ileal segment of the rat intestine at $30 \mathrm{~min}$ after the intragastric administration of ${ }^{65} \mathrm{Zn}$ ( $4 \mu \mathrm{Ci} ; 16 \mu \mathrm{Ci} / \mu \mathrm{mol}$ zinc chloride) a: $\mathrm{d}(c)$ the duodenum at $18 \mathrm{~h}$ after the intraperitoneal injection of $\mathrm{ZnCl}_{2}(25 \mu \mathrm{mol})$.

from either the duodenum (Fig. 2(a)) or the jejuno-ileal segment (Fig. 2(b)) at $30 \mathrm{~min}$ after the oral administration of ${ }^{65} \mathrm{Zn}$, both stable and radioactive $\mathrm{Zn}$ were found to be located in the high (H)- medium (M)- and low (L)-molecular-weight (MW) regions of the elution profile ( $V_{\mathrm{e}} / V_{\mathrm{o}}$ of the column being $1 \cdot 0-1 \cdot 8,1 \cdot 8-2 \cdot 7$ and $2 \cdot 7-3.0$ respectively).

The LMW fraction (possibly the free cation or amino acid complexes thereof) was not resolved into subfractions by gel filtration on Sephadex G 75. Neither this fraction nor the HMW fraction was investigated further. The MMW fraction, which bound a greater proportion of the total soluble ${ }^{65} \mathrm{Zn}$ in the duodenum (Fig. 2(a)) than in the jejuno-ileal segment (Fig. 2(b)), resembled the $\mathrm{Zn}$-induced $\mathrm{ZnMT}$ in its elution characteristics. Hepatic $\mathrm{ZnMT}$, added at a concentration of $65 \mu \mathrm{g} \mathrm{MT}$-bound $\mathrm{Zn}$ to appropriate volumes (equivalent to $1 \mathrm{~g}$ initial wet weight of tissue) of the soluble fractions from these intestinal segments, was recovered without loss of $\mathrm{Zn}$ in the MMW fraction at $V_{\mathrm{e}} / V_{\mathrm{o}} 2$.

lon-exchange chromatography of each of these MMW fractions on DEAE cellulose, however, yielded only one major peak of protein-bound $\mathrm{Zn}\left({ }^{\circ}{ }^{65} \mathrm{Zn}\right)$, which eluted at low 


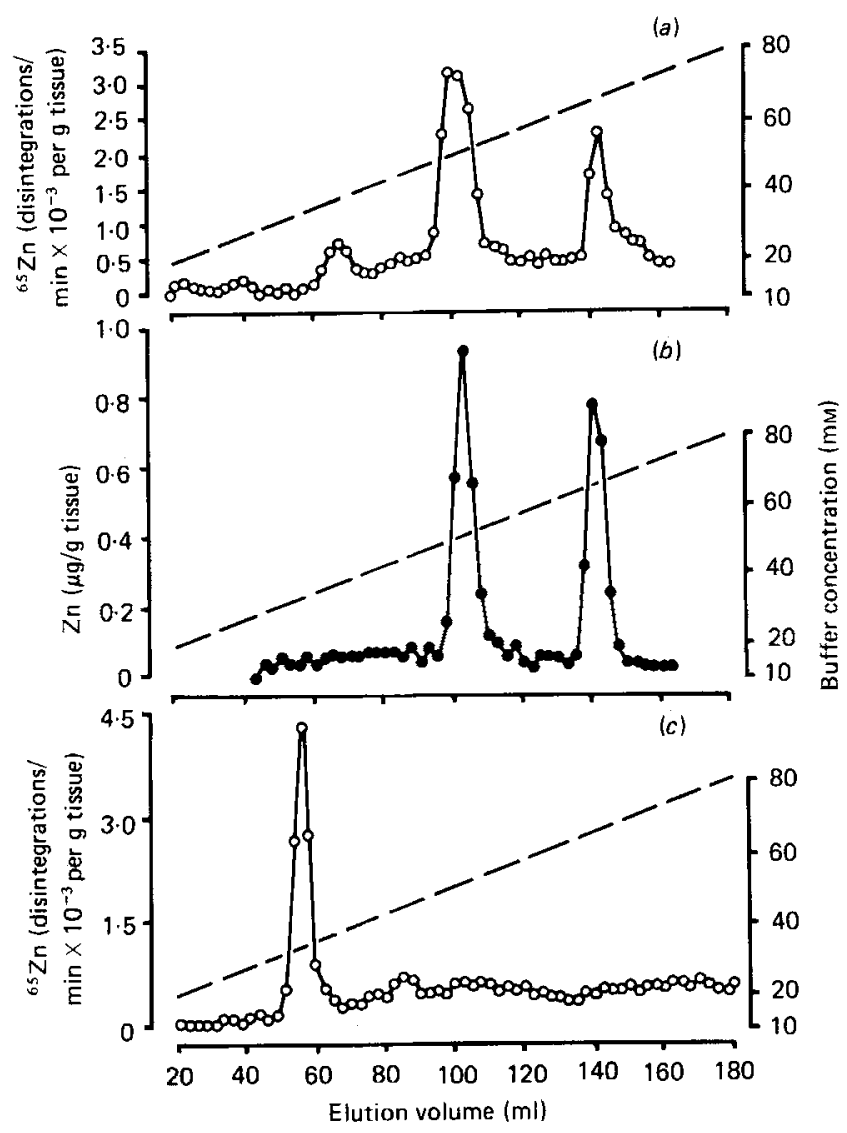

Fig. 5. Ion-exchange chromatography on DEAE-cellulose columns $(300 \mathrm{~mm} \times 15 \mathrm{~mm}$ ) with a linear gradient (--) of 10-200 mM-ammonium formate buffer, $\mathrm{pH} 8 \cdot 0$, as eluant, of the ${ }^{65} \mathrm{Zn}$-labelled medium-molecular-weight, physiological Zn-binding protein fractions A $(a)$ and B (c) from the duodenum (see Fig. 4(a)) and $\mathrm{Zn}$ metallothionein (MT) (b) from the duodenum of the rat injected intraperitoneally with $\mathrm{Zn}$ (see Fig. $4(c)$ ). $\mathrm{Zn},(O) ;{ }^{65} \mathrm{Zn},(\mathrm{O})$. In $(b)$ the MT-isomers, ZnMT-I and ZnMT-II, eluted at buffer concentrations of $50 \mathrm{mM}$ and $65 \mathrm{~mm}$ respectively.

ionic strength (Fig. 3(a,b)). A similar weakly-charged metal-binding protein fraction was obtained by fractionation of an anaerobically-prepared duodenal homogenate after the addition of sufficient $\mathrm{Cd}$ (sixfold molar excess over the endogenous $\mathrm{Zn}$ ) to displace the bound $\mathrm{Zn}$ and to block any free thiol groups. In the MMW fraction of the duodenum of the ${ }^{65} \mathrm{Zn}$-dosed rat, two small additional peaks, the $\mathrm{Zn}$ contents of which were below the limit of detection, were identified by their ${ }^{65} \mathrm{Zn}$ contents (Fig. 3(a)).

The soluble MMW Zn-binding-protein fraction from either the duodenum or the jejuno-ileal segment of the normal rat intestine, which was recovered as a single peak from a $900 \mathrm{~mm} \times 15 \mathrm{~mm}$ column of Sephadex G 75 (Fig. 2), was separated into two peaks (A and B) by filtration through a larger column $(900 \mathrm{~mm} \times 25 \mathrm{~mm})$ of the same gel-matrix at a reduced flow-rate (13-14 $\mathrm{ml} / \mathrm{h}$; i.e. approximately half the usual flow-rate for a column of this size). The relative proportions of the two peaks differed in the soluble fractions from the duodenum (Fig. 4(a)) and the jejuno-ileal segment (Fig. 4(b)). Under the same conditions the ZnMT that was induced in either of the intestinal segments by the parenteral injection of $\mathrm{Zn}$, remained as a single peak (Fig. 4(c)); the elution patterns for the soluble 
fractions from the duodenum and jejuno-ileal segment were identical. Ion-exchange chromatography of fraction A from the normal duodenum yielded two major $\mathrm{Zn}$ containing components (Fig. $5(a)$ ) which, in their elution characteristics, resembled the isoMT that were resolved by the same method from the $\mathrm{Zn}$-induced $\mathrm{ZnMT}$ of the duodenum (Fig. 5(b)) and jejuno-ileal segment. In contrast, most of the protein-bound $\mathrm{Zn}$ in fraction B was eluted from the DEAE-cellulose column as a sharp peak at low ionic strength (Fig. 5(c)) and the presence of the MT isomers (or similarly-charged proteins) was not detected. Fraction $\mathrm{B}$ from the jejuno-ileal segment also yielded a $\mathrm{Zn}$-binding protein that eluted at a low, but apparently slightly higher ionic strength ( $42 \mathrm{~mm}$-ammonium formate) than that from fraction B of the duodenum (i.e. $36 \mathrm{mM}$-ammonium formate; Fig. $5(\mathrm{c})$ ). Fraction $\mathrm{A}$ from the jejuno-ileal segment, however, gave a diffuse distribution pattern (values not shown), possibly indicative of the separation of ionic Zn during chromatography, with the resolution of only one small peak which, from its position in the elution profile, may have been ZnMT-I.

\section{DISCUSSION}

From previous studies (Jackson et al. 1981) it is probable that, at $30 \mathrm{~min}$ after the oral administration of ${ }^{65} \mathrm{Zn}$ under the conditions of the present experiments, about $60 \%$ of the dose had been removed from the intestinal lumen and the majority of the absorbed ${ }^{65} \mathrm{Zn}$ remained within the gut wall. At this time the elution profile of ${ }^{65} \mathrm{Zn}$ that was obtained by gel filtration of the soluble components of the duodenum on a $900 \mathrm{~mm} \times 15 \mathrm{~mm}$ column of Sephadex G 75 was qualitatively similar but quantitatively different from that of the endogenous $\mathrm{Zn}$ (Fig. 2(a)). Thus although the largest amounts of both stable and radioactive $\mathrm{Zn}$ were present in the HMW-protein fraction, which probably contained the proteins of $10^{5} \mathrm{MW}$ that Kowarski et al. (1974) consider to be concerned with Zn transport, the specific activity (total counts/total $\mathrm{Zn}$ ) of this fraction (20500 disintegrations/min per $\mu \mathrm{g} \mathrm{Zn}$ ) was appreciably less than that of the MMW fraction (44900 disintegrations/min per $\mu \mathrm{g} \mathrm{Zn}$ ). In the jejuno-ileal segment (Fig. 2(b)), in which the distribution of stable $\mathrm{Zn}$ in the soluble proteins was similar to that in the duodenum, the specific activities of the HMW and MMW fractions were about the same (17900 and 19800 disintegrations/min per $\mu \mathrm{g}$ $\mathrm{Zn}$ respectively). It seems, therefore, that although the latter fraction of the duodenal mucosa contained only about $20 \%$ of the total soluble $\mathrm{Zn}$, it was particularly avid in the binding of lumen $\mathrm{Zn}$ and, therefore, may be important in the process of $\mathrm{Zn}$ absorption.

Under the above-defined conditions of gel filtration the elution characteristics of the duodenal MMW fraction were similar to those of the MT, which was induced in both the duodenum and the jejuno-ileal segment of the rat by parenteral adminstration of $\mathrm{ZnCl}_{2}(25$ $\mu \mathrm{mol}$ ). However, the assumption, made by Starcher et al. (1980) and by Sugawara (1982), that the physiological MMW Zn-binding fraction from the whole rat intestine can be identified as MT on the basis of its behaviour on gel filtration is erroneous. The MMW $\mathrm{Zn}$-binding fractions from both the duodenum and the jejuno-ileal segment of the intestine of the normal rat, which were obtained as single peaks (Fig. $2(a, b)$ ) under these conditions, were heterogeneous. Both yielded at least four $\mathrm{Zn}$-containing protein fractions on highperformance liquid chromatography (D. Holt, M. J. Jackson and M. Webb, unpublished results) and were resolved by gel filtration on a larger column at a reduced flow-rate into two metalloprotein fractions (Fig. 4(a,b)). The ZnMT, induced in the intestine by excess $\mathrm{Zn}$, however, remained as a single peak under these conditions (Fig. 4(c)). Nevertheless, the change in the dimensions or flow-rate of the initial Sephadex G 75 column, or both, affected the elution characteristics of the isometallothioneins, ZnMT-I and ZnMT-II, when these were separated by subsequent ion-exchange chromatography on a $300 \mathrm{~mm} \times 15 \mathrm{~mm}$ column of DEAE cellulose (see Figs 1 and $5(b)$ ). 
The first fraction (peak A), which was isolated from the duodenum of the normal rat by the modified gel-filtration procedure, was separated by ion-exchange chromatography into two major $\mathrm{Zn}$ proteins (Fig. 5(a)) which, in their elution characteristics, were identical to the isometallothioneins, ZnMT-I and ZnMT-II (Fig. 5(b)). The second peak (B) from the duodenum, which had a lower relative MW than that of peak $A$ and thus could not be a MT-polymer, yielded only one major $\mathrm{Zn}$ protein of low charge on ion-exchange chromatography (Fig. 5(c)). This weakly-charged species remained after treatment of an anaerobically-prepared homogenate, before fractionation, with a metal $(\mathrm{Cd})$ of much higher binding affinity for thionein than $\mathrm{Zn}$ (Webb, 1979) and thus seems unlikely to have been an artifact, due to the intramolecular oxidation of a $\mathrm{Zn}$-undersaturated MT during the isolation procedures. Furthermore, on ion-exchange chromatography, peak B from the jejuno-ileal segment also yielded a $\mathrm{Zn}$-protein fraction, similar to that from peak $\mathbf{B}$ of the duodenum. Analyses by Dr I. Bremner, according to the method of Mehra \& Bremner (1983), however, showed that the MMW fraction from the jejuno-ileal segment, in contrast to that from the duodenum, did not have immunoreactivity against an antibody to rat liver ZnMT-I.

Analysis of the heat-stable $\left(90^{\circ} / 4 \mathrm{~min}\right)$ components of homogenates of intestinal segments by pulse polarography led Flanagan et al. (1983) to conclude that, in the mouse, the duodenum contains the largest concentration of MT. The results of the present work also suggest that MT isomers are located mainly in the duodenum of the normal rat and form two of several MMW Zn-binding proteins which are rapidly labelled after the administration of ${ }^{65} \mathrm{Zn}$ by gavage. This suggests that they may be functional in $\mathrm{Zn}$ absorption although the presence of non-specific metal binding ligands which do not play a role in Zn absorption cannot be discounted. Nevertheless, comparison of Figs. 3(a) and $5(a)$ suggests that the content of MT in the duodenal mucosa may be very variable. This variation seems unlikely to be due to differences in proteolysis during the preparative and fractionation procedures, since hepatic $\mathrm{ZnMT}$, added to the soluble fractions from the intestinal segments, was recovered unchanged in the subsequent gel filtration. This is in contrast to the observation of Cousins et al. (1978) that high proteolytic activity of the rat intestinal mucosa leads to the rapid hydrolysis of $\mathrm{ZnMT}$ and other $\mathrm{Zn}$-binding proteins in the isolated cytosol with the formation of LMW $(<2000) \mathrm{Zn}$ complexes. Restriction of food intake in the rat is known to increase the $\mathrm{Zn}$ and $\mathrm{ZnMT}$ contents of the liver (Bremner \& Davies, 1975 ) and it is therefore possible that the concentrations of the MT isomers in the duodenum are also influenced by starvation. In the present work some experiments were undertaken using fed animals (results not shown), but quantitative comparison of the results with those for starved rats was not possible, since the presence of digesta in the intestines interfered with the absorption of ${ }^{65} \mathrm{Zn}$. Nevertheless, it was clear from these studies that the presence of ZnMT-I and ZnMT-II in the duodenum was not an artifact due to starvation.

The authors are extremely grateful to Dr Ian Bremner (Rowett Research Institute, Aberdeen) for the radioimmunoassay of the MMW fractions from the duodenum and jejuno-ileal segment for MT-I.

Bonewitz, R. E., Foulkes, E. C., O'Flaherty, E. J. \& Hertsberg, V. (1982). In Biological Roles of Metallothionein, pp. 203-214 [E. C. Foulkes, editor]. New York: Elsevier/North-Holland.

Bremner, I. (1982). In Trace Element Metabolism in Man and Animals, pp. 637-644 [J. M. Gawthorne, J. McC. Howell and C. L. White, editors]. Berlin, Heidelberg and New York: Springer-Verlag.

Bremner, I. \& Davies, N. J. (1975). Biochemical Journal 149, 733-738. 


\section{Zinc-binding proteins of rat gut}

Cousins, R. J. (1979). Nutrition Reviews 37, 97-103.

Cousins, R. J., Smith, K. T., Failla, M. L. \& Markowitz, L. A. (1978). Life Sciences 23, 1819-1826.

Davies, N. T. (1980). British Journal of Nutrition 43, 189-203.

Elmes, M. E., Golden, M. I. \& Love, A. H. G. (1976). Quarterly Journal of Medicine 45, 696 697.

Flanagan, P. R., Haist, J. \& Valberg, L. S. (1983). Journal of Nutrition 113, 962-972.

Hall, A. C., Young, B. W. \& Bremner, I. (1979). Journal of Inorganic Biochemistry 11, 57-66.

Hurley, L. S., Duncan, J. R., Swan, M. V. \& Eckhert, C. D. (1977). Proceedings of the National Academy of Sciences, USA 74, 3547-3549.

Jackson, M. J., Jones, D. A. \& Edwards, R. H. T. (1981). British Journal of Nutrition 46, 15-27.

Kowarski, S., Blair-Stanek, C. S. \& Schachter, D. (1974). American Journal of Physiology 226, 401-407.

Mehra, R. K. \& Bremner, I. (1983). Biochemical Journal 214, 459-465.

Menard, M. P., McCormick, C. C. \& Cousins, R. J. (1981). Journal of Nutrition 111, 1353-1361.

Menard, M. P., Oestreicher, P. \& Cousins, R. J. (1983). In Nutritional Bioavailability of Zinc, American Chemical Society Symposium Series no. 210, pp. 233-246 [G. E. Inglett, editor]. Washington DC: American Chemical Society.

Moynahan, E. J. (1974). Lancet ii, 399-400.

Olafson, R. W. (1983). Journal of Nutrition 113, 268-275.

Richards, M. P. \& Cousins, R. J. (1975). Biochemical and Biophysical Research Communications 64, 1215-1223.

Richards, M. P. \& Cousins, R. J. (1976). Proceedings of the Society for Experimental Biology and Medicine 153, 52-56.

Richards, M. P. \& Cousins, R. J. (1977). Biochemical and Biophysical Research Communications 75, $286-294$.

Starcher, B. C., Glauber, J. C. \& Madras, J. G. (1980). Journal of Nutrition 110, 1391-1397.

Sugawara, N. (1982). In Biological Roles of Metallothionein, pp. 155-162 [E. C. Foulkes, editor]. New York: Elsevier/North-Holland.

Taguchi, T. \& Nakamura, K. (1982). Journal of Toxicology an Environmental Health 9, 401-409.

Webb, M. [editor] (1979). In The Chemistry, Biochemistry and Biology of Cadmium, pp. 195-266. New York: Elsevier/North Holland. 